\title{
Growth and Flowering of Five Mango Cultivar under Subtropics Conditions of Brazil
}

\author{
Andréa Carvalho da Silva ${ }^{1}$, Adilson Pacheco de Souza ${ }^{1 *}$, Sarita Leonel ${ }^{2}$, Manoel Euzébio de Souza ${ }^{2}$, \\ Dayana Portes Ramos², Adriana Aki Tanaka ${ }^{2}$ \\ ${ }^{1}$ Institute of Agricultural and Environmental Sciences, Federal University of Mato Grosso, Sinop, Brazil; ${ }^{2}$ Department of Plant Pro- \\ duction, School of Agronomic Sciences, State University of Sao Paulo, Botucatu, Brazil. \\ Email: acarvalho@ufmt.br,
}

Received November $17^{\text {th }}$, 2013; revised January $17^{\text {th }}$, 2014; accepted January $29^{\text {th }}, 2014$

Copyright (C) 2014 Andréa Carvalho da Silva et al. This is an open access article distributed under the Creative Commons Attribution License, which permits unrestricted use, distribution, and reproduction in any medium, provided the original work is properly cited. In accordance of the Creative Commons Attribution License all Copyrights (C) 2014 are reserved for SCIRP and the owner of the intellectual property Andréa Carvalho da Silva et al. All Copyright (C) 2014 are guarded by law and by SCIRP as a guardian.

\section{ABSTRACT}

The evaluation of the new cultivars adaptation and yield potential of Mangifera indica L. provides tools to assist and improve the mango production in different climates conditions. This study aimed to evaluate the phenological and reproductive development of five mango cultivars (Bourbon, Haden, Palmer, Parwin and Tommy Atkins), on climate conditions in dry land and four production cycles (from 08/2007 to 01/2011), at São Manuel, São Paulo state, Brazil. The variables were total plant height, trunk height, stem diameter and the first insertion diameter, fruits physical characteristics, yield and harvest period, flowering seasonality and morphological characterization of the inflorescences. It was found that the four-year-old plants of Haden cv. reach $4.0 \mathrm{~m}$ high and $0.20 \mathrm{~m}$ of trunk diameter. Bourbon cultivar had the highest flowering period, from April to October. Tommy Atkins cv. had productivities of $14779.07 \mathrm{~kg} \cdot \mathrm{ha}^{-1}$ in the fourth cycle and the productivity of Bourbon, Haden and Palmer cultivars was alternated.

\section{KEYWORDS}

\section{Mangifera indica L.; Phenology; Environmental Factors}

\section{Introduction}

The increases of cultivated area and fruits productivity in different Brazilians climate regions are dependent of modernization and improvements in rural property management and production factors, such as deployment of efficient production systems and enabling ideal physiological conditions for plant development, with the adoption of technologies with low environmental impact, that provide product quality and safety to comply with the national market requirements and phytosanitary barriers for importers [1-3].

The commercial Brazilian mango is grounded in a few American cultivars. The Tommy Atkins cultivar occupies approximately $80 \%$ of the planted area and it provides a narrowing genetic and a productivity decrease due to

"Corresponding author. entomological problems and/or phytopathological [4,5]. The mango cultivars that have greater acceptance by the Brazilians consumers are from the subtropical climate region and it behaves differently when grown in tropical conditions. The genetic heritage of several species has become increasingly used with the agribusiness expansion which caused extensive phenoltypic changes to comply with the main sponsors needs of the production chain: producers, distributors and consumers.

In this context, the producers seek varieties with higher productivity, yield stability, easy handling in cultivation, adapted to adverse climate conditions where it will be developed. The distributors need varieties with greater resistance to handling and transport, while consumers seek the best quality fruits, with emphasis on the color and flavor $[6,7]$. 
The growth of the mango trees is usually given by cycles with short repetitions throughout the year and it is depending on the cultivar, climate conditions and management [8]. The knowledge about the growth pattern of the mango trees is essential for establishing effective methods to handle the culture and it allows the phenoltypic characteristics expressions of each genetic material. Among the mango trees phenophases, the flowering is a complex phenomenon as long as its duration and it may be extended earlier by natural conditions or artificial inductions, it depends on climatic conditions and previous crop productivity [5,9-11].

The mango trees have higher productions in regions with cold and/or dry period preceding flowering, humid soil and maximum air temperature between $30^{\circ} \mathrm{C}$ and $33^{\circ} \mathrm{C}$ during the fruit development. Temperatures above $35^{\circ} \mathrm{C}$ cause injury in plants and temperatures from $8^{\circ} \mathrm{C}$ to $10^{\circ} \mathrm{C}$ during the cold period of the year, may be regarded as the lower limit for the successful mango production $[12,13]$. A temperature regime of $25^{\circ} \mathrm{C}$ during the day and $15^{\circ} \mathrm{C}$ during the night as prevails during this period was found to be the optimum for flower induction [14]. Prior to flowering, farmers do not irrigate in order to enhance drought stress to support flower induction. Flowering intensity of mangoes was found to negatively correlate with relative water content [15].

The knowledge of the phenology of other mango cultivars can be used for genetic breeding or even for cultivation in new planting areas and on the range of processes linked to agronomic management of the supply chain, it is important to know the periodic biological events involving the development of this species.

Considering that, the mango can get place in the regional agricultural development, assessments of species climate adaptation and the cultivars with potential for cultivation are essential for displaying options for crops diversification. Seeking to present options for diversification of cultivars with potential for cultivation and adapted for São Paulo State climate conditions this paper aimed to evaluate the phenological and reproductive development of five mango cultivars (Tommy Atkins, Bourbon, Haden, Palmer and Parwin), in São Manuel, São Paulo State, Brazil.

\section{Materials and Methods}

The study was conducted from August 2007 to January 2010 in São Manuel Experimental Farm, Faculty of Agricultural Sciences (FCA), UNESP, São Manuel, São Paulo state, located at $22^{\circ} 44^{\prime} \mathrm{S}, 48^{\circ} 34^{\prime} \mathrm{W}$ and altitude of 740 meters. The soil is classified as Red Yellow Latosol [16]. The climate is classified as Cfa, it is characterized as warm temperate (mesothermal), with rains in the summer and dry in the winter, with annual average of air temperature and precipitation about $21^{\circ} \mathrm{C}$ and $1530 \mathrm{~mm}$
[17]. The air temperature and rainfall variation during the study period (Figure 1) were provided by the Department of Natural Resources/Environmental Sciences, of FCA/UNESP.

The seedlings were grafted onto Espada cultivar and there were planted at $5.00 \times 4.50 \mathrm{~m}$ spacing (between rows and plants) totaling 444 plants $\mathrm{ha}^{-1}$, with transplant occurring in February/2006. Intensive cultivation was conducted following the techniques recommended by Campbell \& Wasielewski [18] for the culture, and the soil samplings were evaluated annually to verify the needs of fertilizer and soil correction.

The experimental design was randomized blocks with 10 plants per experimental cultivar (Tommy Atkins, Bourbon, Haden, Palmer and Parwin) (Figure 2). The characteristics of vegetative development were assessed

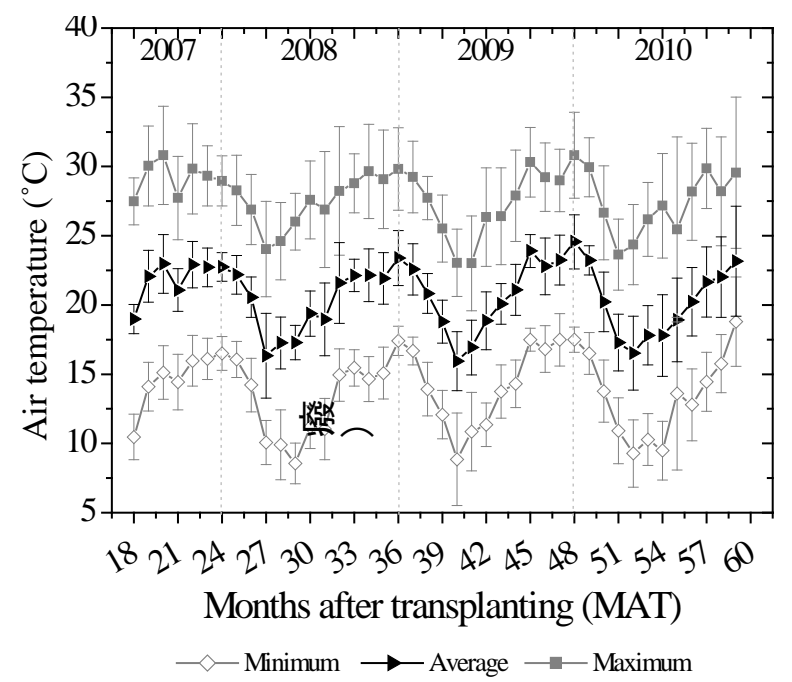

(a)

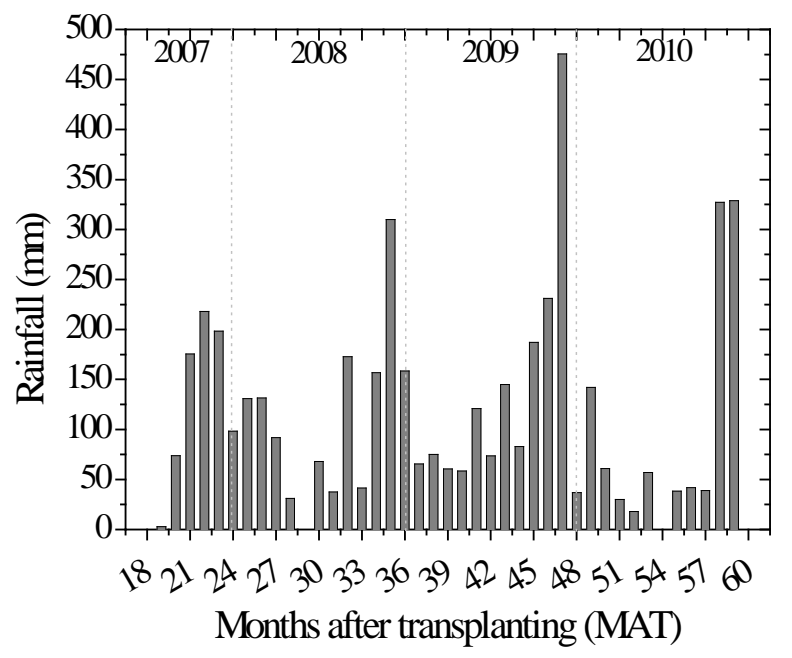

(b)

Figure 1. Air temperature (a) and rainfall (b) between August 2007 (18th month) and January 2011, in São Manuel, São Paulo state, Brazil. 
cv. Bourbon
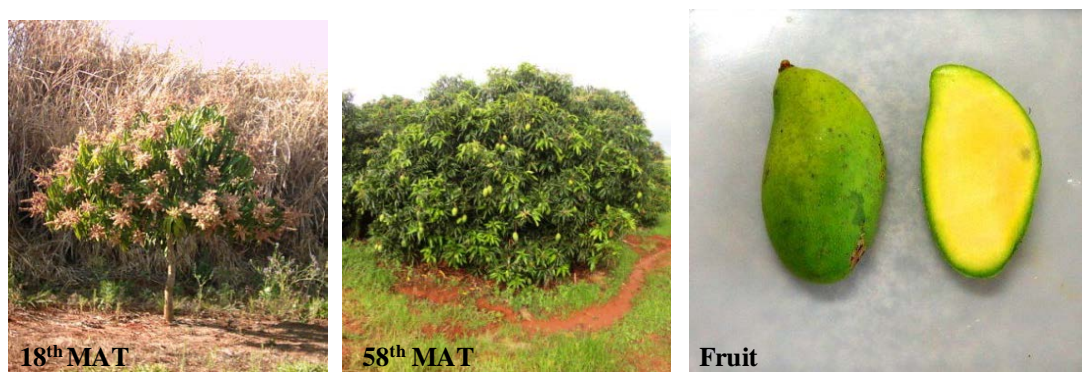

cv.Haden

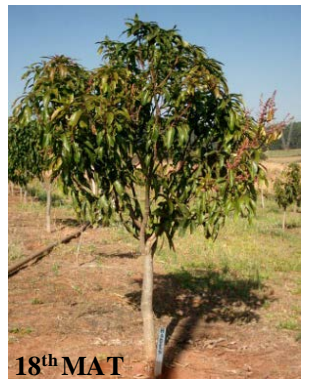

cv. Palmer
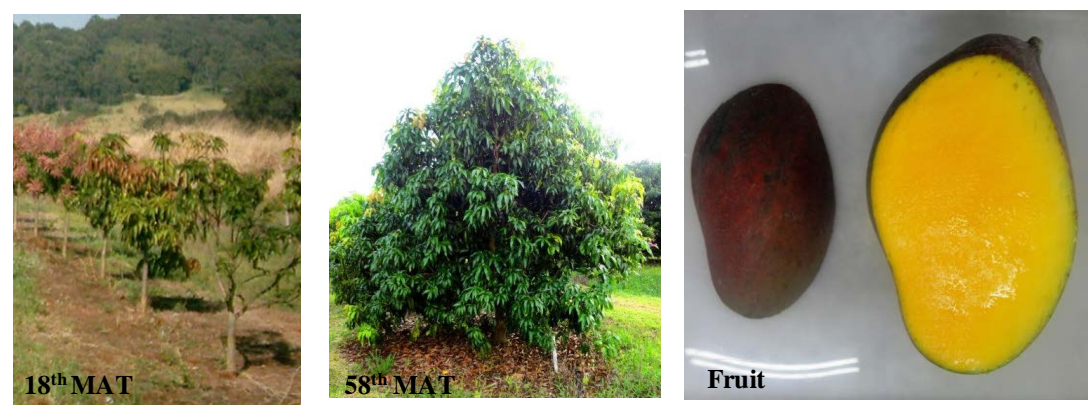

cv. Parwin
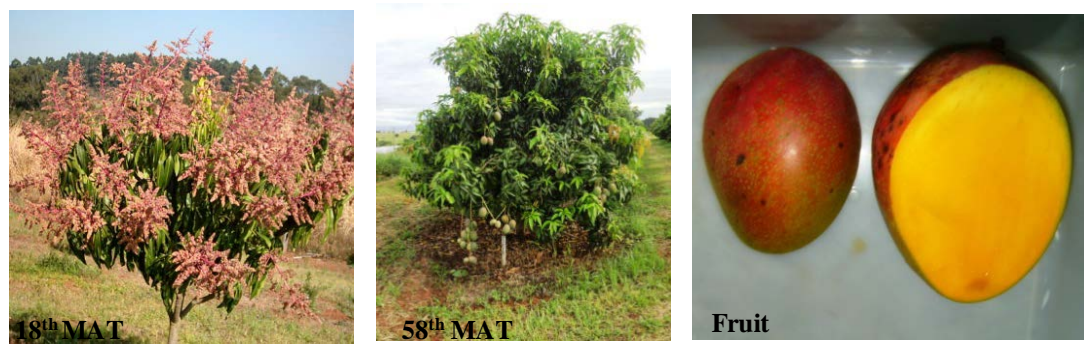

cv. Tommy Atkins
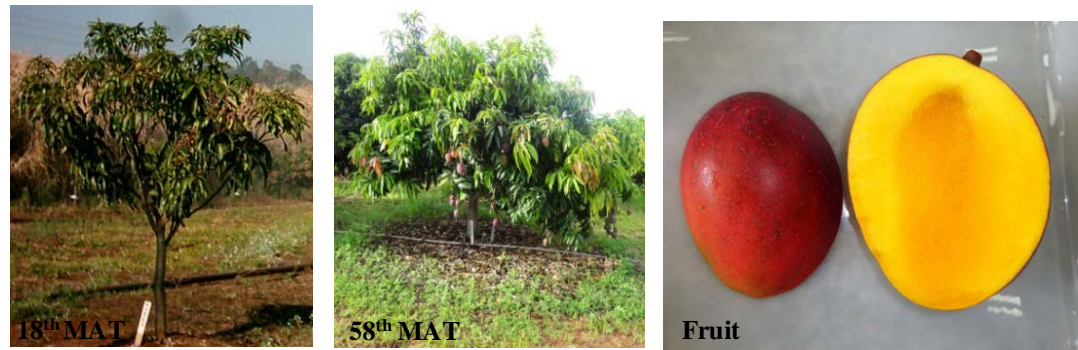

Figure 2. Pictures of five mango cultivars evaluated between August 2007 (18th MAT) and January 2011 (58th MAT), in São Manuel, São Paulo state, Brazil. 
monthly (between 08/2007 and 01/2011): total plant height, trunk height (between the ground level and to the residue of grafting), stem diameter (measured $0.03 \mathrm{~m}$ above the ground), the first insert diameter (measured at $0.03 \mathrm{~m}$ from the stem) and the production variables: number of fruits, fresh mass, longitudinal and equatorial diameter of fruit, productivity and harvest period, seasonality of flowering measured by quantification and morphological characterization of panicles fully formed through the length $(\mathrm{cm})$, base diameter $(\mathrm{mm})$, number of secondary stems of panicle, number of fertilized ovaries (diameters greater than $3 \mathrm{~mm}$ ), number of open flowers, fertilization rate (\%) and dry weight (g).

The data were submitted to variance analysis by $\mathrm{F}$ test and when significant they were compared by Tukey test at $5 \%$ significance level.

\section{Results and Discussion}

The mango trees grown in more than 100 countries distributed in tropical or subtropical latitudes that provides weather conditions for the occurrence of vegetative flows between autumn and summer, as rising temperatures allow higher rates of cell division and a good enzyme functioning that increase dry matter and new organs [19].

It is noted that the low temperatures occurring in the third cycle (Figure 1) between the 39th and 45th month after transplanting (MAT) and it delayed the increases in plant height for Parwin, Tommy Atkins, Palmer and Bourbon cultivars when compared to previous cycles. According to Chacko [20], the optimum temperature for mango trees vegetative growth is located between 20 and $29^{\circ} \mathrm{C}$, and when it is below $15^{\circ} \mathrm{C}$ this stimulate intense flowering.

According Davenport \& Núnez-Elisea [8] the growth of mango trees is ephemeral in tropical conditions, with periodic initiation of vegetative or reproductive shoots occurs from resting buds of terminal stems in several flushes per year. Generally vegetatively induced flushes of growth occur during warm spring, summer, and early fall months [21,22]. In subtropics, the ambient temperature is the primary regulator of vegetative or reproductive induction at the time of shoot initiation. The cold and dry periods are essential to the mango trees flowering and wet periods favor vegetative flows emissions [14, 23-25].

It is observed in Figure 3 that regardless of the season, there was a continuous increase in plant height in the four evaluated cycles. The Haden cv. had an average height of $3.96 \pm 0.24 \mathrm{~m}$, while the others cultivars maintained growth rates similar in height, incorporating in this period $2.95 \pm 0.14,3.37 \pm 0.12,2.85 \pm 0.30$ and $2.52 \pm$ $0.30 \mathrm{~m}$ for Bourbon, Tommy Atkins, Palmer and Parwin respectively. With the Haden exception, trends stabilization was observed in the growth between May and September. The Haden cultivar showed a strong apical dominance, it can be considered high to four years old tree and this fact limits the harvest.

The relative growth rate of the plant may indicate the system's ability to synthesize plant assimilatory (source) and allocate the organic matter in various organs (drains) that rely on photosynthesis, respiration and transport of photoassimilates that allow differentiation of organs, over a period of time, influenced by biotic and abiotic stresses to the plant [26]. Note that there is similarity of relative growth rates of cultivar Parwin when compared with the other, with two peaks of higher growth in each production cycle (Figure 4). The reduction in GRG was due to the decrease in rainfall and air temperature.

According Ramos et al. [27] the rootstock "Sword" or "Common" provides to canopy mango trees a vigorous growth that hinders the culture treatment and harvesting, in addition to increasing losses in post-harvest. These authors observed for "Tommy Atkins" and "Haden" with 6.5-year-old plants that they had 3.81 and $3.77 \mathrm{~m}$ in height at Brasília (DF) weather conditions.

Regarding to the trunk diameter, there was an increase of 10.82, 15.02, 13.62, 11.14 and $10.45 \mathrm{~cm}$ for Bourbon, Haden, Tommy Atkins, Palmer and Parwin, with average values after 59 MAT $14.22 \pm 1.14,20.33 \pm 1.37,16.11 \pm$ $0.72,13.23 \pm 1.66$ and $14.05 \pm 1.24$, respectively. About the plant height and trunk diameter variables were not significant differences among cultivars Bourbon, Palmer and Parwin (Table 1), while "Tommy Atkins" showed increments of $3.25 \mathrm{~cm}$ in the trunk diameter between 48 and 58 MAT. These growth rates result primarily of vascular activity, which is strongly influenced by factors such as photoperiod, rainfall, nutrient availability and plants spatial distribution [28].

For the trunk height variable (obtained from the ground level to the residue of grafting) observed the growth highest rates in production cycles I (2007/2008) and IV (2010/2011) for all cultivars. It was found in this

Table 1. Averages of mango trees growth variables at the end of the fourth production cycle (59th month after transplantation), in São Manuel (SP).

\begin{tabular}{ccccc}
\hline Cultivar & $\begin{array}{c}\text { Plant } \\
\text { height }(\mathrm{m})\end{array}$ & $\begin{array}{c}\text { Trunk } \\
\text { height }(\mathrm{m})\end{array}$ & $\begin{array}{c}\text { Trunk } \\
\text { diameter }(\mathrm{cm})\end{array}$ & $\begin{array}{c}\text { First insertion } \\
\text { diameter }(\mathrm{cm})\end{array}$ \\
\hline $\begin{array}{c}\text { Bourbon } \\
\text { Haden }\end{array}$ & $2.95 \mathrm{~b}$ & $0.89 \mathrm{ab}$ & $14.22 \mathrm{c}$ & $4.47 \mathrm{c}$ \\
Tommy & $2.94 \mathrm{a}$ & $0.96 \mathrm{a}$ & $20.33 \mathrm{a}$ & $8.50 \mathrm{a}$ \\
Atkins & $0.84 \mathrm{~b}$ & $16.11 \mathrm{~b}$ & $7.37 \mathrm{ab}$ \\
Palmer & $2.55 \mathrm{~b}$ & $0.84 \mathrm{~b}$ & $13.28 \mathrm{c}$ & $6.94 \mathrm{~b}$ \\
Parwin & $2.46 \mathrm{~b}$ & $0.72 \mathrm{c}$ & $13.03 \mathrm{c}$ & $6.37 \mathrm{bc}$ \\
CV(\%) & 9.67 & 10.87 & 9.73 & 20.85 \\
DMS & 0.54 & 0.11 & 1.41 & 2.03 \\
\hline
\end{tabular}

Means followed by the same letter in the column do not differ by Tukey test at $5 \%$ probability. 


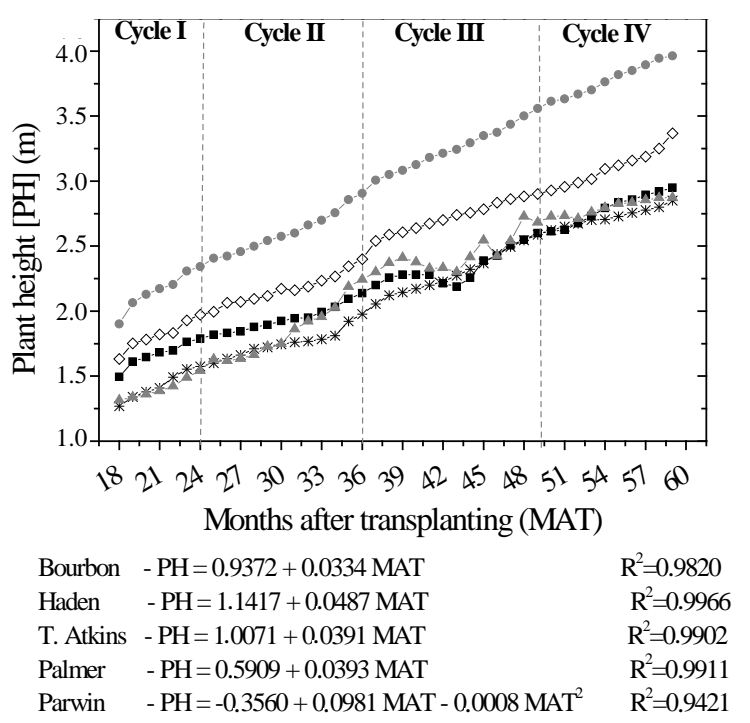

(a)

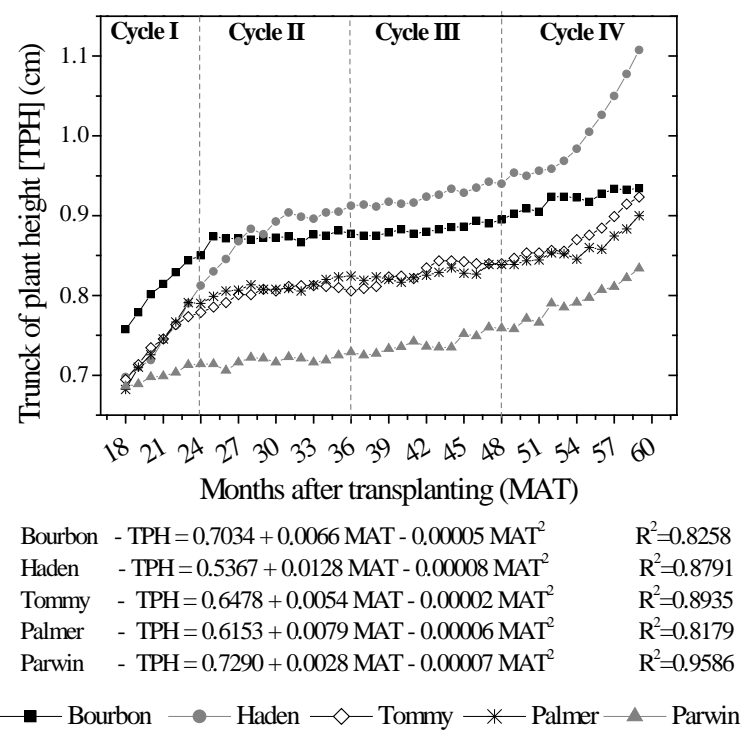

(c)

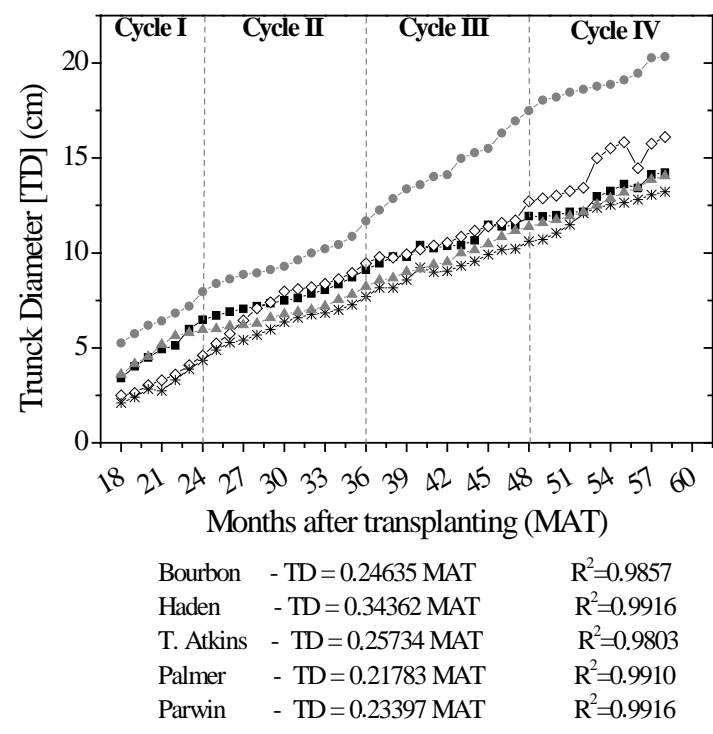

(b)

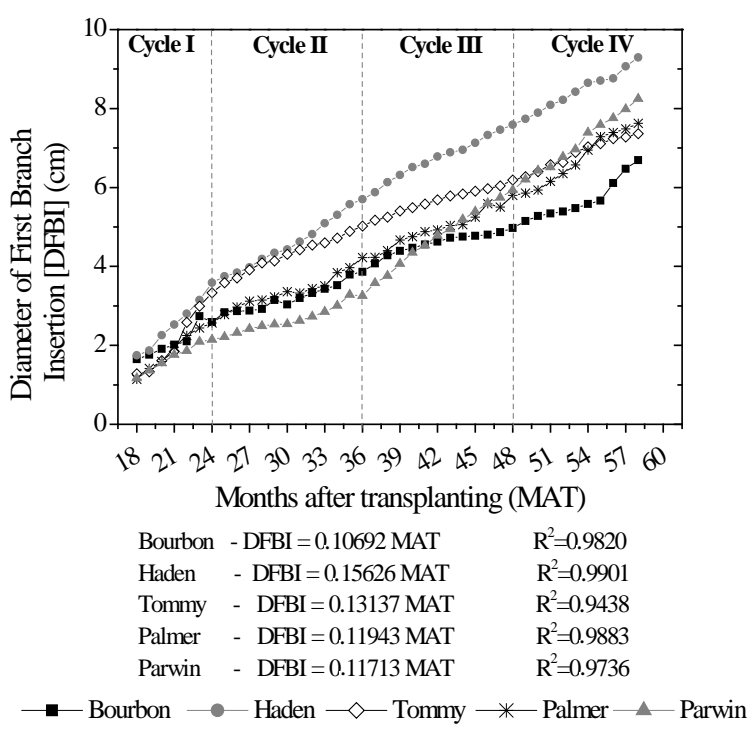

(d)

Figure 3. Mango trees growth curves and equations by plant height (a), trunck diameter (b), trunck of plant height (c) and diameter of first branch insertion (d), during four productive cycles, in São Manuel, São Paulo State, Brazil.

case, a sigmoidal growth trend with fast incorporating in height, stabilization and recovery, which was not observed for the other growth curves that showed linear trends for the variables. After 59 MAT, the average trunks heights were $0.93 \pm 0.07,1.11 \pm 0.12,0.92 \pm 0.12$, $0.90 \pm 0.09$ and $0.83 \pm 0.12 \mathrm{~m}$ for Bourbon, Haden, Tommy Atkins, Palmer and Parwin. In general, the five cultivars showed linear increase on the first insertion diameter (first branch) with increments of 5.04, 7.54, 6.09, 6.49 and $7.08 \mathrm{~cm}$ for the aforementioned cultivars respectively.

The morphological changes on the parameters evaluated of increase terms about volume, mass, linear dimensions and structural units occurred due to the pho- toassimilates in the carbohydrates storage and production form such as structural material retained in the lignified tissues [26]. Despite low temperatures $\left(<10^{\circ} \mathrm{C}\right)$ occurred generally in July and August (Figure 1), the plants growth continued over the four crop cycles, however, points out that as the mango trees are usually characterized by a slow vegetative growth in its juvenile stage and higher growth rates in adulthood [29].

The adjusted regressions represent the growth progression over the four production cycles, allowing to observe the growth pattern variations in the studied cultivars attributes (plant height, stem diameter, height and trunk diameter of first insertion) due the variability. The linear models were obtained for the trunk diameter and the first 


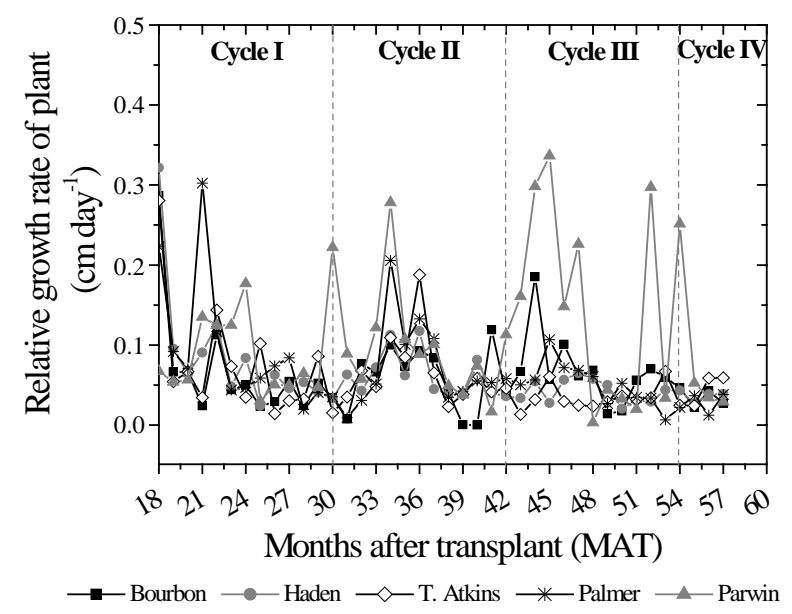

Figure 4. Relative growth rate (RGR) of mango trees, during four productive cycles, in São Manuel, São Paulo State, Brazil (beginning of measures in August 2007-18th month after transplantation).

insert in all cultivars, while for plant height only "Parwin" was quadratic due to the imbalance between the vegetative and reproductive stages (Figure 3), whereas this cultivar has a large number of panicles and fruit development in the reproductive phase which in turn decreases the reserves allocation to trunks and roots, which are used in the new vegetative growth fluxes.

The mango trees flowering is an important physiological event that defines the beginning of the fruits production and according Ramírez \& Davenport [25] it happens due to the existence of a flowering promoter synthesized in the leaves and translocated by the phloem to new sprouts. In the local climatic conditions, the onset of flowering found were: April to "Bourbon" (early), May to "Haden", "Tommy Atkins" and "Palmer" and in June to 'Parwin' (Late). Therefore, the end of flowering occurred in September for "Haden" and in October for the others, with an average duration respectively $(57,61,75$, 148 and 62 days). The Bourbon variety presented new inflorescences grown with panicles still under development, i.e., together with the fruit development, these new emissions were subjected to high humidity and infection especially for anthracnose (Colletotrichum gloeosporioides), and it needed a larger phytosanitary care.

The cultivars flowering culminated with low measured rainfall and temperatures (Figure 1), and the pattern and duration of phenological development stages depends on environmental conditions and adaptation of each variety to specific environments $[18,28,30]$. The panicles number per cultivar varied between the evaluated cycles. In the first cycle, the largest mean differences were observed between "Parwin" (23.30) and "Bourbon" (5.88), while in the other production cycles, many inflorescences were observed in cultivar Bourbon (102.13, 109.38 and 301) with peaks in June and July (Table 2).
Table 2. Inflorescence average number per mango tree during four productive cycles, in São Manuel, São Paulo State, Brazil.

\begin{tabular}{|c|c|c|c|c|c|}
\hline Date & Bourbon & Haden & $\begin{array}{l}\text { Tommy } \\
\text { Atkins }\end{array}$ & Palmer & Parwin \\
\hline \multicolumn{6}{|c|}{ 2007/2008 Cycle } \\
\hline 8/31/2007 & 5.88 & 15.30 & 5.78 & 9.50 & 23.30 \\
\hline 9/26/2007 & 0.38 & 4.50 & 5.33 & 6.80 & 13.10 \\
\hline \multicolumn{6}{|c|}{ 2008/2009 Cycle } \\
\hline $5 / 20 / 2008$ & 4.26 & 0 & 0 & 0 & 0 \\
\hline $6 / 25 / 2008$ & 55.13 & 21.88 & 19.11 & 2.89 & 0 \\
\hline 7/28/2008 & 102.13 & 45.75 & 23.11 & 9.56 & 9.78 \\
\hline 8/27/2008 & 4.38 & 19.00 & 12.22 & 22.00 & 13.00 \\
\hline $9 / 24 / 2008$ & 76.88 & 2.75 & 0.67 & 1.75 & 3.78 \\
\hline $10 / 31 / 2008$ & 7.50 & 0 & 0 & 0.11 & 0 \\
\hline \multicolumn{6}{|c|}{ 2009/2010 Cycle } \\
\hline $5 / 27 / 2009$ & 8.13 & 0 & 0 & 0 & 0 \\
\hline 6/29/2009 & 109.38 & 12.88 & 7.67 & 14.33 & 1.40 \\
\hline 7/21/2009 & 6.88 & 5.75 & 1.22 & 5.22 & 33.10 \\
\hline 8/15/2009 & 98.13 & 98.00 & 98.00 & 85.44 & 60.60 \\
\hline $9 / 16 / 2009$ & 13.00 & 45.38 & 0 & 5.89 & 9.40 \\
\hline 10/30/2009 & 69.00 & 0.00 & 8.00 & 17.56 & 44.33 \\
\hline \multicolumn{6}{|c|}{ 2010/2011 Cycle } \\
\hline $4 / 30 / 2010$ & 22.25 & 0 & 0 & 0 & 0 \\
\hline $5 / 26 / 2010$ & 166.00 & 26.50 & 5.00 & 3.00 & 0 \\
\hline 6/29/2010 & 176.63 & 152.75 & 79.33 & 119.33 & 32.20 \\
\hline $7 / 28 / 2010$ & 301.00 & 301.75 & 182.00 & 150.67 & 171.20 \\
\hline $8 / 25 / 2010$ & 65.13 & 6.13 & 0 & 6.00 & 115.30 \\
\hline $9 / 28 / 2010$ & 14.88 & 150.50 & 26.11 & 65.11 & 34.00 \\
\hline $10 / 27 / 2010$ & 43.10 & 0 & 0 & 13.22 & 15.80 \\
\hline
\end{tabular}

In August (at the third cycle) there was a synchronization of panicles peak emergence due to the low rainfall that occurred between 28 and 30 months after transplanttation (MAT). The highest number of panicles was observed in the fourth cycle for all cultivars and, in this case the lowest values were obtained for "Palmer" and "Tommy Atkins", however, they were the best cultivars due to higher rates of fertilization.

Due to the great variability in panicles (inflorescences) morphological characteristics for all cultivars and four evaluated cycles (Table 3), it was adopted as the reference lengths of $20 \mathrm{~cm}$ to "Bourbon" and $35 \mathrm{~cm}$ for the other cultivars to classification of large and small panicles. The panicles classified as large for Haden, Tommy Atkins, Palmer and Parwin were 17.00, 18.25, 18.12 and $13.37 \mathrm{~cm}$ respectively above the large Bourbon cv. panicles $(23.38 \mathrm{~cm})$, which in this case showed the smallest panicle diameter $(5.65 \mathrm{~mm})$. These results confirm the observations made by Mouco et al. [31], who reported to 
Table 3. Mango trees panicles morphological characteristics and fertilization index during four productive cycles, in São Manuel, São Paulo state, Brazil.

\begin{tabular}{|c|c|c|c|c|c|c|c|}
\hline Cultivar & Length (cm) & Diameter (mm) & $\mathrm{NS}^{*}$ & $\mathrm{NO}^{*}$ & $\mathrm{NFl}^{*}$ & $\mathrm{DM}(\mathrm{g})$ & FP (\%) \\
\hline \multicolumn{8}{|c|}{ Large panicles } \\
\hline Haden & 40.38 a & $8.00 \mathrm{ab}$ & 46.40 a & 249.8 a & 2159.7 a & 14.96 a & $10.53 \mathrm{bc}$ \\
\hline Tommy & $41.63 \mathrm{a}$ & $9.75 \mathrm{a}$ & $39.25 \mathrm{ab}$ & $162.0 \mathrm{ab}$ & $2101.7 \mathrm{a}$ & $12.95 \mathrm{ab}$ & 9.22 bc \\
\hline Bourbon & $23.38 \mathrm{~b}$ & $5.65 \mathrm{~b}$ & $29.00 \mathrm{~b}$ & $25.8 \mathrm{c}$ & 1648.5 b & $4.94 \mathrm{c}$ & $0.76 \mathrm{c}$ \\
\hline Palmer & $41.50 \mathrm{a}$ & $8.30 \mathrm{ab}$ & $41.50 \mathrm{ab}$ & $215.3 \mathrm{ab}$ & $552.6 \mathrm{c}$ & $11.30 \mathrm{ab}$ & $28.18 \mathrm{a}$ \\
\hline Parwin & 36.75 a & $7.00 \mathrm{ab}$ & $31.50 \mathrm{~b}$ & 84.5 bc & $315.1 \mathrm{c}$ & 6.88 bc & $17.87 \mathrm{ab}$ \\
\hline \multicolumn{8}{|c|}{ Small panicles } \\
\hline Haden & $28.00 \mathrm{a}$ & $6.43 \mathrm{ab}$ & $32.00 \mathrm{a}$ & $238.0 \mathrm{ab}$ & $1253.4 \mathrm{ab}$ & $6.22 \mathrm{ab}$ & $17.33 \mathrm{bc}$ \\
\hline Tommy & 32.38 a & $7.73 \mathrm{a}$ & 31.75 a & $337.3 \mathrm{a}$ & 1594.3 a & $8.83 \mathrm{a}$ & $13.31 \mathrm{bc}$ \\
\hline Bourbon & $19.03 \mathrm{~b}$ & $4.70 \mathrm{~b}$ & 27.50 a & $8.5 \mathrm{c}$ & $1082.1 \mathrm{ab}$ & $2.99 \mathrm{c}$ & $1.82 \mathrm{c}$ \\
\hline Palmer & $24.50 \mathrm{ab}$ & $5.65 \mathrm{ab}$ & 28.25 a & $127.0 \mathrm{ab}$ & 261.1 c & $3.21 \mathrm{c}$ & $48.93 \mathrm{a}$ \\
\hline Parwin & 27.85 a & $5.03 \mathrm{~b}$ & 24.75 a & $84.0 \mathrm{~b}$ & $288.7 \mathrm{c}$ & $5.52 \mathrm{ab}$ & $32.90 \mathrm{ab}$ \\
\hline
\end{tabular}

*NR: Number of secondary steam of panicle; NO: Number of fertilized ovaries; NFl: number of opened flowers; DM: dry mass; FP: fertilization percentage (\%). Means followed by the same letter in the column and the class of panicle, do not differ by Tukey test at $5 \%$ probability.

the Kent cultivar in Petrolina (PE), average values of panicle length equal to $39.00 \mathrm{~cm}$. Regarding the panicles development degree, it was observed that the number of secondary steam of the panicle also differed among the genotypes.

Haden and Bourbon cultivars showed the highest and lowest amounts of axis (46.40 and 29.00), while "Tommy Atkins" and "Palmer" did not differ in the panicles size (Table 3). Therefore they had significant differences in the number of fertilized ovaries and the extremes average was observed in "Haden" (249.8) and "Bourbon" (25.8). It was found regardless of the panicles size that the largest number of hermaphrodite open flowers was obtained for Haden and Tommy Atkins cultivars.

The highest panicle dry mass were obtained in "Haden" (14.96 g) due to the high vigor and growth of these structural bodies, however, the largest panicles are susceptible of the flowers falls due to wind gusts. The mango is a fruit species that has low fertilization rate and the data have revealed this information. The highest and lowest rates of fertilization occurred in Palmer cultivars (28.05\% and $48.93 \%$ ) and Bourbon (0.76\% and 1.82\%) for panicle classified as large and small, respectively. It was found about 2159.7 and 2101.7 flowers (male, female and hermaphrodite) opened in Haden and T. Atkins.

According Siqueira et al. [32], in general the major commercial cultivars have flowers around 1009 (between male and hermaphrodite). The mango cultivars normally differ in their floral and vegetative behavior, especially in relation to the duration of the juvenile stage when derived from inbred plants and grafted plants. The plants propagation from seed has a long juvenility period (ranging from three to ten years) [33].
Correlations between panicles length and mass are in Table 4, with slopes of 0.8542, 0.5906, 0.7362, 0.534 and 0.7565 for Tommy Atkins, Parwin, Haden, Palmer and Bourbon cultivars respectively, with correlation coefficients (r) greater than 0.7372 for all cultivars. The productive characteristics of five cultivars showed significant differences between production cycles, genetic materials, and the alternation of production (Table 5).

The Bourbon fruits did not show growth during the first cycle, however, the maximum fruits number in formation increased with plant age (8.00, 12.25 and 24.40), however, the number of fruits in the reproductive period did not persist until the harvest time (occurred between January and February).

They were harvested on average nine "Haden" fruits in the third and fourth cycle, however for this cultivar the highest yield was obtained in the second cycle (5339.61 $\left.\mathrm{kg} \cdot \mathrm{ha}^{-1}\right)$. The Palmer cultivar presented the harvest period from December to February (45 days) corroborating with Braz et al. [34] in Visconde do Rio Branco, Minas Gerais state, Brazil.

This cultivar showed the highest values of fruit fresh mass of 405.08, 562.00 and $537.88 \mathrm{~g}$ for the cycles I, II and IV, which amounted average yield of 1474.25; 3439.44; 6961.45 and $6344.41 \mathrm{~kg} \cdot \mathrm{ha}^{-1}$, respectively. This yield was lower than the values found by Carvalho et al. [35] for plants of 6 and 7 years old (18,469 and 26,231 $\mathrm{kg} \cdot \mathrm{ha}^{-1}$ ) in Votuporanga, São Paulo state, Brazil, considering that it can be attributed to the warmer climate of the city, which is more favorable to the mango cultivation. The Parwin cultivar showed low fruit set when it comparing the number of fruits and maximum number of fruit formation. The maximum of harvested fruits was 
Table 4. Morphological characteristics correlations between mango trees panicles during four productive cycles, in São Manuel (SP).

\begin{tabular}{cccccc}
\hline \multirow{2}{*}{ Cultivar } & \multicolumn{2}{c}{$\begin{array}{c}\text { Length } \times \text { Dry mass } \\
\left\langle\mathrm{DM}=\mathrm{a}_{0} \mathrm{C}\right\rangle\end{array}$} & \multicolumn{2}{c}{$\begin{array}{c}\text { Ratio C/ } \mathrm{D}^{* * *} \times \text { Fertilization (\%) } \\
\left\langle\mathrm{F}=\mathrm{a}_{0} \mathrm{C} / \mathrm{D}+\mathrm{a}_{1}\right\rangle\end{array}$} \\
\cline { 2 - 6 } & $\mathrm{a}_{0}$ & $\mathrm{R}^{2}$ & $\mathrm{a}_{0}$ & $\mathrm{a}_{1}$ & 0.7944 \\
Haden & 0.3819 & 0.7362 & -0.8166 & 53.0590 & 0.7711 \\
Tommy Atkins & 0.3060 & 0.8542 & -0.3033 & 25.9731 & 0.7847 \\
Bourbon & 0.2704 & 0.5434 & -0.1565 & 7.4882 & 0.6954 \\
Palmer & 0.1496 & 0.7565 & -0.6087 & 74.885 & 0.7824 \\
Parwin & 0.1467 & 0.5906 & -0.2411 & 36.4170 & $\mathrm{R}^{2}$ \\
\hline
\end{tabular}

*Panicle dry mass, include secondary steam of panicle, inflorescences, flowers and fruits; ${ }^{* *}$ Ratio between length (cm) and diameter (cm).

Table 5. Mango trees productive characteristics during four cycles, in São Manuel (SP).

\begin{tabular}{|c|c|c|c|c|c|c|}
\hline Cultivar & MNF & NHF & FFM (g) & $\begin{array}{c}\text { Equatorial diameter } \\
(\mathrm{mm})\end{array}$ & $\begin{array}{l}\text { Longitudinal diameter } \\
\qquad(\mathrm{mm})\end{array}$ & $\begin{array}{c}\text { Productivity } \\
\left(\mathrm{kg}^{-} \mathrm{ha}^{-1}\right)\end{array}$ \\
\hline \multicolumn{7}{|c|}{ Productive cycle-2007/2008 } \\
\hline Bourbon & - & - & - & - & - & - \\
\hline Haden & $2.00 \mathrm{~b}$ & $2.00 \mathrm{~b}$ & $85.75 b$ & 30.88 a & $36.13 \mathrm{~b}$ & 143.25 c \\
\hline Palmer & $7.87 \mathrm{~b}$ & $3.64 \mathrm{~b}$ & $405.08 \mathrm{a}$ & 62.25 a & 97.63 a & $1474.25 \mathrm{~b}$ \\
\hline Parwin & 94.13 a & $5.25 \mathrm{ab}$ & $344.07 \mathrm{ab}$ & 54.25 a & $67.88 \mathrm{ab}$ & 1806.38 b \\
\hline Tommy Atkins & $13.34 \mathrm{~b}$ & $13.00 \mathrm{a}$ & $235.00 \mathrm{ab}$ & 52.50 a & $62.00 \mathrm{ab}$ & 3055.02 a \\
\hline \multicolumn{7}{|c|}{ Productive cycle—2008/2009 } \\
\hline Bourbon & $8.00 \mathrm{~b}$ & $4.38 \mathrm{c}$ & $218.50 \mathrm{~b}$ & $36.00 \mathrm{~b}$ & $60.00 \mathrm{~b}$ & $957.00 \mathrm{~b}$ \\
\hline Haden & $53.87 \mathrm{ab}$ & $14.16 \mathrm{ab}$ & $377.13 \mathrm{ab}$ & $72.63 \mathrm{ab}$ & $81.38 \mathrm{ab}$ & 5339.61 a \\
\hline Palmer & $56.25 \mathrm{ab}$ & 6.12 bc & $562.00 \mathrm{a}$ & $87.00 \mathrm{a}$ & $135.00 \mathrm{a}$ & $3439.44 \mathrm{ab}$ \\
\hline Parwin & 74.13 a & $11.63 \mathrm{~b}$ & $325.25 \mathrm{ab}$ & $76.13 \mathrm{ab}$ & $118.13 \mathrm{ab}$ & $3782.66 \mathrm{ab}$ \\
\hline Tommy Atkins & $52.25 \mathrm{ab}$ & 22.68 a & $299.38 \mathrm{ab}$ & $54.38 \mathrm{ab}$ & $61.88 \mathrm{~b}$ & 6700.12 a \\
\hline \multicolumn{7}{|c|}{ Productive cycle-2009/2010 } \\
\hline Bourbon & 59.25 c & 10.87 a & $361.25 \mathrm{~b}$ & $47.00 \mathrm{~b}$ & 67.38 c & $3926.79 \mathrm{~b}$ \\
\hline Haden & 37.50 c & $9.25 \mathrm{a}$ & $249.00 \mathrm{~b}$ & $61.38 \mathrm{ab}$ & 71.75 bc & 2303.25 b \\
\hline Palmer & $175.75 \mathrm{~b}$ & 15.38 a & $452.63 \mathrm{ab}$ & 80.25 a & 120.63 a & 6961.45 a \\
\hline Parwin & $251.38 \mathrm{~b}$ & 17.50 a & $418.75 \mathrm{ab}$ & 82.88 a & $110.75 \mathrm{ab}$ & 7328.13 a \\
\hline Tommy Atkins & $532.50 \mathrm{a}$ & 16.13 a & 523.50 a & 88.89 a & $109.88 \mathrm{ab}$ & 8444.06 a \\
\hline \multicolumn{7}{|c|}{ Productive cycle-2010/2011 } \\
\hline Bourbon & 24.40 c & $4.91 \mathrm{c}$ & $179.43 \mathrm{~b}$ & $39.59 \mathrm{~b}$ & $57.18 \mathrm{c}$ & 1299.78 b \\
\hline Haden & $36.25 \mathrm{bc}$ & $9.13 \mathrm{c}$ & $431.00 \mathrm{a}$ & 83.00 a & $93.00 \mathrm{~b}$ & $3935.03 \mathrm{~b}$ \\
\hline Palmer & $76.34 \mathrm{~b}$ & $26.57 \mathrm{~b}$ & 537.88 a’ & 83.85 a & 131.38 a & $6344.41 \mathrm{ab}$ \\
\hline Parwin & 374.45 a & $41.15 \mathrm{ab}$ & 414.65 a & 78.53 a & $109.70 \mathrm{ab}$ & $7576.63 \mathrm{ab}$ \\
\hline Tommy Atkins & $117.05 \mathrm{~b}$ & $67.49 \mathrm{a}$ & 493.18 a & 87.15 a & $106.81 \mathrm{ab}$ & $14,779.07$ a \\
\hline
\end{tabular}

MNF: Maximum number of fruits; NHF: number of harvested fruits; FFM: Fruit fresh mass; Means followed by the same letter in the column do not differ significantly at $5 \%$ probability by Tukey test.

observed only in the third cycle (13.38) with fresh mass ranging from 325.25 to 452.53 and productivity 1806.38 to $7576.63 \mathrm{~kg} \cdot \mathrm{ha}^{-1}$.

The Tommy Atkins cultivar was the most productive $\left(14779.07 \mathrm{~kg} \cdot \mathrm{ha}^{-1}\right)$, with harvests concentrated between December and February (45 days) and it was without alternation in the studied productive cycles. Carvalho et al. [35] reported production of $14,036 \mathrm{~kg} \cdot \mathrm{ha}^{-1}$ in 7 years old plants. This cultivar is considered one of the most planted in the country because it is productive, it has excellent shell color and good response to floral induction. In general, this cultivar in adulthood should produce an 
average of $40 \mathrm{t} \cdot \mathrm{ha} \mathrm{a}^{-1}$ with plant density of $476 \mathrm{ha}^{-1}$, it has low height and open canopy, early and regular production, besides it is moderately tolerant to major pests and diseases, fruits with fresh mass ranging 400 to $500 \mathrm{~g}$ and oval-shaped [6].

\section{Conclusions}

Four-year-old plants of Mangifera indica L. Haden cv. reach $4.0 \mathrm{~m}$ in height and $20 \mathrm{~cm}$ in trunk diameter, with large size and limitations for harvesting. Bourbon cultivar has the highest flowering period (April to October), with low rates of panicles fertilization, which provides low productivity.

At São Manuel-SP conditions to rainfed crops, Tommy Atkins four-year-old plants show an average yield of $14779.07 \mathrm{~kg} \cdot \mathrm{ha}^{-1}$. Parwin cultivar presents a high number of fruits information during the reproductive phase and this causes them to need pruning to improve the production quality and seasonality.

The Tommy Atkins and Palmer cultivars stand as alternative to cultivation in São Manuel (SP) region and other places with similar climatic conditions.

\section{REFERENCES}

[1] J. C. Fachinello, M. S. Pasa, J. D. Schmtiz and D. L. Betemps, "Situation and Prespectives of Temperate Fruit Crops in Brazil,” Revista Brasileira de Fruticultura, Vol. 33, No. 1, 2011, pp. 109-120. http://dx.doi.org/10.1590/S0100-29452011000500014

[2] J. B. Retamales, "World Temperate Fruit Production: Characteristics and Challenges," Revista Brasileira de Fruticultura, Vol. 33, No. 1, 2011, pp. 121-130. http://dx.doi.org/10.1590/S0100-29452011000500015

[3] M. A. Tecchio, J. E. Bettiol Neto, W. Barbosa and M. L. S. A. Tucci, "Evolution and Perspective of the Temperate Fruit Crops in São Paulo State, Brazil,” Revista Brasileira de Fruticultura, Vol. 33, No. 1, 2011, pp. 150-157. http://dx.doi.org/10.1590/S0100-29452011000500018

[4] J. A. Galli, A. L. M Martins, M. F. Ito, M. T. Braghini, N. Narita and C. J. Rossetto, "Mango wilt XXII. Survival of Poliembrionic Varieties," Revista Brasileira de Fruticultura, Vol. 33, No. 4, 2011, pp. 1119-1126. http://dx.doi.org/10.1590/S0100-29452011000400010

[5] J. A. L. Silva and J. A. Neves, "Combination of Paclobutrazol, Potassium Sulfate and Ethephon on Floral Induction of Mango cv. Tommy Atkins," Comunicata Scientiae, Vol. 2, No. 1, 2011, pp. 18-24.

[6] A. C. Q. Pinto, F. P. Neto and T. G. Guimarães, "Mango Breeding Strategies on Focus Tot the Dynamic of the Market," Revista Brasileira de Fruticultura, Vol. 33, No. 1, 2011, pp. 64-72. http://dx.doi.org/10.1590/S0100-29452011000500009

[7] C. A. F. Sousa, M. I. L. G. Cavalcanti, L. F. L. Vasconcelos, H. U. Sousa, V. Q. Ribeiro and J. A. L. Silva, “Tommy Atkins Mango Trees Subjected to High Density
Planting in Subhumid Tropical Climate in Northeastern Brazil,” Pesquisa Agropecuária Brasileira, Vol. 47, No. 1, 2012, pp. 36-43. http://dx.doi.org/10.1590/S0100-204X2012000100006

[8] T. L. Davenport and R. Núñez-Elisea, "Reproductive Physiology,” In: R. E. Litz, Ed., The Mango: Botany, Production and Uses, CAB International, Wallingford, 1997, pp. 69-146.

[9] J. H. Huang, W. H. Ma, G. L. Liang, L. Y. Zhang, W. X. Wang, Z. J. Cai and S. X. Wen, "Effects of Low Temperatures on Sexual Reproduction of 'Tainong 1' Mango (Mangifera indica)," Scientia Horticulturae, Vol. 126, No. 1, 2010, pp. 109-119.

http://dx.doi.org/10.1016/j.scienta.2010.06.017

[10] V. Mendonça, S. E. A. Neto, O. M. Hafle, J. B. Menezes and J. D. Ramos, "Flowering and Frutification of Mango with Use of Paclobutrazol, Ethephon e Calcium Nitrate,” Revista Brasileira de Fruticultura, Vol. 23, No. 2, 2001, pp. 265-269. http://dx.doi.org/10.1590/S0100-29452001000200012

[11] M. A. C. Mouco, E. O. Ono and J. D. Rodrigues, “Control of Vegetative Growth and Flowering on Mango cv. Kent with Plant Growth Regulators,” Revista Brasileira de Fruticultura, Vol. 33, No. 4, 2011, pp. 1043-1047. http://dx.doi.org/10.1590/S0100-29452011000400001

[12] Z. H. Shu and T. F. Sheen, "Floral Induction in Axillary Buds of Mango (Mangifera indica L.) as Affected by Temperature," Scientia Horticulturae, Vol. 31, No. 1, 1987, pp. 81-87. http://dx.doi.org/10.1016/0304-4238(87)90109-9

[13] G. L. F. Portela, M. G. Lima, L. E. M. Padua, F. A. S. Neto and A. B. G. Martins, "Agroclimatic Zoning of Mango Crop in the State of Piaui," Revista Brasileira de Fruticultura, Vol. 30, No. 4, 2008, pp. 1036-1039. http://dx.doi.org/10.1590/S0100-29452008000400032

[14] N. Sukhvibul, A. W. Whiley, M. K. Smith, S. E. Hetherington and V. Vithanage, "Effect of Temperature on Sex Expression of Mono and Poly-Embryonic Mango (Mangifera indica L.) Cultivars," Journal of Horticultural Science and Biotechnology, Vol. 74, No. 1, 1999, pp. 6468.

[15] W. Pongsomboon, R. A. Stephenson, A. W. Whiley and S. Subhadrabandu, "Development of Water Stress and Stomatal Closure in Juvenile Mango (Mangifera indica L.) Trees," Acta Horticulturae (ISHS), No. 321, 1992, pp. 496-503.

[16] H. G. Santos, P. K. T. Jacomine, L. H. C. Anjos, V. A. Oliveira, J. B. Oliveira, M. R. Coelho, J. F. Lumbreras and T. J. F. Cunha, "Sistema Brasileiro de Classificação de Solos,” 2nd Edition, Embrapa Solos, Rio de Janeiro, 2006.

[17] A. R. Cunha and D. Martins, "Climatic Classification for Districts of Botucatu and São Manuel, São State, Brazil,” Irriga, Vol. 41, No. 1, 2009, pp. 1-11.

[18] R. Campbell and J. Wasielewski, "Mango Tree Training Techniques for the Hot Tropics," Acta Horticulturae (ISHS), No. 509, 2000, pp. 641-652.

[19] P. M. Hernández Delgado, M. Aranguren, C. Reig, D. 
Fernández Galván, C. Mesejo, A. Martínez Fuentes, V. Galán Saúco and M. Agustí, "Phenological Growth Stages of Mango (Mangifera indica L.) According to the BBCH Scale," Scientia Horticulturae, Vol. 130, No. 3, 2011, pp. 536-540.

http://dx.doi.org/10.1016/j.scienta.2011.07.027

[20] E. K. Chacko, “Mango Flowering-Still an Enigma!” Acta Horticulturae (ISHS), No. 291, pp. 12-21.

[21] T. L. Davenport, Z. Ying, V. Kulkarni and T. L. With, "Evidence for a Translocate Florigenic Promoter in Mango,” Scientia Horticulturae, Vol. 110, No. 2, 2006, pp. 150-159. http://dx.doi.org/10.1016/j.scienta.2006.06.029

[22] A. C. Q. Pinto, F. G. Faleiro, V. H. V. Ramos, M. C. R. Cordeiro, S. R. M. Andrade, N. T. V. Junqueira and J. N. Dias, "Performance of Seven New Mango (Mangifera indica L.) Hybrid Selections at the Central Region of Brazil,” Acta Horticulturae, Vol. 820, No. 1, 2009, pp. 137146.

[23] N. Sukhvibul, A. W. Whiley, M. K. Smith, S. E. Hetherington and V. Vithanage, "Effect of Temperature on Inflorescence and Floral Development in Four Mango (Mangifera indica L.) Cultivars," Scientia Horticulturae, Vol. 82, No. 1, 1999, pp. 67-84. http://dx.doi.org/10.1016/S0304-4238(99)00041-2

[24] W. Spreer, S. Ongprasert, M. Hegele, J. N. Wunsche and J. Muller, "Yield and Fruit Development in Mango (Mangifera indica L. Cv. Chok Anan) under Different Irrigation Regimes," Agricultural Water Management, Vol. 96, No. 4, 2009, pp. 574-584.

http://dx.doi.org/10.1016/j.agwat.2008.09.020

[25] F. Ramírez and T. L. Davenport, "Mango (Mangifera indica L.) Flowering Physiology," Scientia Horticulturae, Vol. 126, No. 1, 2010, pp. 65-72. http://dx.doi.org/10.1016/j.scienta.2010.06.024

[26] A. C. Silva, S. Leonel, A. P. Souza, M. E. Souza and A. A. Tanaka, "Fig Tree Growth under Different Crop Conditions,” Pesquisa Agropecuária Tropical, Vol. 41, No. 4, 2011, pp. 539-551. http://dx.doi.org/10.5216/pat.v41i4.13223

[27] V. H. V. Ramos, A. C. Q. Pinto and A. C. Gomes, “Avaliation of Seven Mono and Poli-Embryonic Rootstocks in four Cultivars of Mango in Brazilian Cerrado," Revista Brasileira de Fruticultura, Vol. 23, No. 3, 2001, pp. 622629.

http://dx.doi.org/10.1590/S0100-29452001000300036

[28] L. Lojan, "Tendencias del Crecimiento Radial de 23 Especies Forestales del Trópico,” Turrialba, Vol. 18, No. 3, 1968, pp. 275-281.

[29] V. G. Galán Saúco, “El Cultivo del Mango,” MundiPrensa, Madrid, 1999.

[30] H. Lambers, F. S. Chapin III and T. L. Pons, "Plant Physiological Ecology,” Springer Verlag, New York, 1998. http://dx.doi.org/10.1007/978-1-4757-2855-2

[31] M. A. C. Mouco, E. O. Ono and J. D. Rodrigues, "Synthesis Inhibitors of Gibberellins and Mango "Tommy Atkins' Seedlings Growth,” Ciência Rural, Vol. 40, No. 2, 2010, pp. 273-279.

http://dx.doi.org/10.1590/S0103-84782010000200004

[32] K. M. M. Siqueira, L. H. P. Kiill, C. F. Martins, I. B. Lemos, S. P. Monteiro and E. A. Feitoza, "Comparative Study of Pollination of Mangifera indica L. in Conventional and Organic Crops in the Region of the Submedium São Francisco Valley,” Revista Brasileira de Fruticultura, Vol. 30, No. 2, 2008, pp. 303-310. http://dx.doi.org/10.1590/S0100-29452008000200006

[33] E. M. Ataíde, "Effect of Different Ranges of Potassium Nitrate Application in the Flowering and Yield of Mango (Mangifera indica L.) cv. Tommy Atkins,” Master Thesis, Federal University of Bahia, Cruz das Almas, 1997.

[34] V. B. Braz, E. S. Nunes, F. A. D’A. Couto and F. M. V. Lelis, "The Effect or Harvest Date and Storage Period on Postharvest Quality of Mango cv. Palmer,” Acta Scientiarum Agronomy, Vol. 29, No. 2, 2007, pp. 263-268. http://dx.doi.org/10.4025/actasciagron.v29i2.269

[35] C. R. L. Carvalho, C. J. Rossetto, D. M. B. Mantovani, J. V. Castro and N. Bortoletto, "Evaluation of Mango Cultivars Selected by Instituto Agronômico de Campinas Compaired to Others of Commercial Importance,” Revista Brasileira de Fruticultura, Vol. 26, No. 2, 2004, pp. 264-271.

http://dx.doi.org/10.1590/S0100-29452004000200021 